УДК 638.224.24

(C) 2013

\author{
Карповський В. І., доктор ветеринарних наук, \\ Максін В. І., доктор хімічних наук, \\ Криворучко Д. І., кандидат ветеринарних наук, \\ Трокоз В. О., кандидат біологічних наук,
}

Tрокоз А. В. аспірант (науковий керівник - доктор ветеринарних наук В. I. Карповський),

Шестеринська В. В., аспірант (науковий керівник - кандидат біологічних наук В. О. Трокоз)

Національний університет біоресурсів і природокористування України

\title{
ДИНАМІКА КІЛЬКОСТІ ЕРИТРОЦИТІВ УКРОВІ СВИНЕЙ РІЗНИХ ТИПІВ ВИЩОЇ НЕРВОВОЇ ДІЯЛЬНОСТІ ПІД ВПЛИВОМ «ЙОДІС-КОНЦЕНТРАТУ»
}

\section{Рецензент - доктор ветеринарних наук А. А. Замазій}

\begin{abstract}
На підставі досліджень, результати яких описані в статті, рекомендується використання сировини для виробництва йодованих продуктів «Йодіс-кониентрат» в якості ефективного профілактичного $i$ лікувального препарату у вирощуванні свиней. Це дає можливість підвищити кількість еритрощчитів у крові тварин, щуо сприяє покращзанню показників реактивності їх організму. Застосування препарату «Йодісконцентрат» у дозі 0,12 мг на 1 кг маси тіла двічі на добу, впродовж 40 діб свиням сприяє збільшенню кількості еритроцитів крові (особливо у тварин сильних типів вищої нервової діяльності), щзо підвищує резистентність їх організму.
\end{abstract}

Ключові слова: свині, реактивність, резистентність, еритроцити, йодіс-конщентрат, вплив.

Постановка проблеми. Продуктивність тварин безпосередньо пов'язана з резистентністю їх організму. Встановлено, що показники резистентності значно відрізняється у різних тварин і залежать, певною мірою, від типологічних особливостей вищої нервової діяльності.

Аналіз основних досліджень і публікацій, у яких започатковано розв'язання проблеми. Відомо, що на рівень реактивності та резистентності організму тварин впливає рухливість, сила та врівноваженість процесів збудження і гальмування в корі півкуль мозку [2]. Еритроцити в організмі тварин виконують життєво важливі функції: транспорт газів і поживних речовин, забезпечення гомеостазу, участь у ферментативних реакціях. Тому стимуляція гемопоезу сприятиме підвищенню рівня захисних сил організму та його продуктивності. Одним із перспективних йодовмісних препаратів $є$ сировина для виробництва йодованих продуктів «Йодісконцентрат», який має яскраво виражені антибактеріальні, фунгіцидні та загальностимулюючі властивості й успішно використовується в медицині, тваринництві та рослинництві $[1,4,5]$.
Вплив препарату «Йодіс-концентрат» на фізіологічний стан свиней, передусім залежно від типологічних особливостей вищої нервової діяльності, недосліджений.

Мета досліджень: вивчити динаміку кількості еритроцитів у крові свиней різних типів вищої нервової діяльності за умов впливу препарату «Йодіс-концентрат».

Завдання досліджень: випробувати препарат «Йодіс-концентрат» у терапевтичній дозі.

Матеріали і методи досліджень. Досліди проводили у виробничих умовах свиноферми ПСП «Гейсиське» Ставищенського р-ну Київської області на свинках великої білої породи 6-7місячного віку, масою 40-50 кг. Типи вищої нервової діяльності (ВНД) встановлювали згідно 3 розробленою нами методикою за результатами аналізу утворення, згасання і переробки руховохарчових умовних рефлексів у вигляді рухової реакції тварини до місця підкріплення кормом. Відповідно до визначених типологічних особливостей сформували 4 дослідні групи тварин по 4 голови у кожній: перша група - сильний врівноважений рухливий тип (СВР), друга - сильний врівноважений інертний (CBI), третя - сильний неврівноважений $(\mathrm{CH})$ і четверта - слабкий тип (C). Тваринам цих груп задавали 3 кормом водний розчин препарату «Йодіс-концентрат» (далі - препарат) у дозі 0,12 мг на 1 кг маси тіла, двічі на добу впродовж 40 діб. Контрольна група (4 голови) була сформована 3 представників чотирьох типів ВНД, які не одержували «Йодісконцентрату». Раціони годівлі та система утримання всіх тварин були ідентичними. Для 3'ясування впливу препарату «Йодіс-концентрат» на кількість еритроцитів крові залежно від типологічних особливостей ВНД досліджували кров, одержану з яремної вени. Зразки досліджуваного матеріалу відбирали кожні 10 діб. 
ВЕТЕРИНАРНА МЕДИЦИНА

Кількість еритроцитів у крові піддослідних тварин, $\times 10^{12} / л$

\begin{tabular}{|l|c|c|c|c|c|}
\hline \multirow{2}{*}{ Група тварин } & \multicolumn{5}{|c|}{ Час дослідження відносно початку дачі } \\
& \multicolumn{5}{|c|}{ «Йос-концентрату» } \\
\cline { 2 - 6 } & до введення & через 10 діб & через 20 діб & через 30 діб & через 40 діб \\
\hline Сильного врівноваже- & $5,70 \pm$ & $6,02 \pm$ & $5,71 \pm$ & $6,20 \pm$ & $6,84 \pm$ \\
ного рухливого типу & 0,19 & 0,21 & 0,19 & 0,07 & $0,15^{* *}$ \\
\hline Сильного врівноваже- & $5,50 \pm$ & $6,19 \pm$ & $6,01 \pm$ & $5,99 \pm$ & $6,61 \pm$ \\
ного інертного типу & 0,25 & $0,05^{* *}$ & 0,31 & 0,31 & 0,57 \\
\hline Сильного неврівнова- & $5,15 \pm$ & $5,83 \pm$ & $5,93 \pm$ & $6,22 \pm$ & $6,76 \pm$ \\
женого типу & 0,11 & 0,22 & 0,08 & 0,04 & $0,20^{* *}$ \\
\hline \multirow{2}{*}{ Слабкого типу } & $4,81 \pm$ & $5,19 \pm$ & $5,71 \pm$ & $5,79 \pm$ & $6,37 \pm$ \\
& 0,14 & 0,18 & 0,08 & 0,17 & $0,08^{*}$ \\
\hline \multirow{2}{*}{ Контрольна } & $5,26 \pm$ & $5,47 \pm$ & $5,73 \pm$ & $6,01 \pm$ & $5,50 \pm$ \\
& 0,14 & 0,14 & 0,22 & 0,29 & 0,23 \\
\hline
\end{tabular}

Примітка: різниця з контролем достовірна за * $\mathrm{p} \leq 0,05,{ }^{*} \mathrm{p} \leq 0,01$

Визначали кількість еритроцитів за допомогою приладу «Пікоскель» згідно з інструкцією. Отримані дані оброблені загальноприйнятими методами статистики в середовищі Microsoft Excel [3].

Результати досліджень. Установлено, що «Йодіс-концентрат» сприяє збільшенню кількості еритроцитів у крові свиней усіх типів ВНД (див. табл.). Найбільша кількість еритроцитів відмічена у крові інтактних свиней СВР типу, що було достовірним порівняно $з$ тваринами $\mathrm{CH}$ та С типів ВНД.

Застосовуючи як біологічно активну речовину для свиней препарат «Йодіс-концентрат», на 10-у добу відмічали достовірне підвищення кількості еритроцитів у крові свиней СВI типу ВНД на $13,16 \%(\mathrm{p} \leq 0,01)$ до контролю й тенденцію до збільшення досліджуваного показника у представників СВР (на 10,05 \%) і СН (на 6,58 \%) типів ВНД. Тварини С типу хоча й характеризувалися підвищенням вивченого показника в цей період дослідження порівняно 3 початковими параметрами, відносно контролю мали на 5,39 \% менше еритроцитів у крові (не достовірно). Це пояснюється слабкістю коркових процесів, які мали нижчий рівень сили, ніж у тварин контрольної групи. Порівняно з початковим показником, у цей період дослідження зареєстроване достовірне підвищення досліджуваного показника у представників CBI та С типів і тенденція до підвищення у тварин СВР та С типів ВНД.

На 20-у добу задавання препарату достовірних змін у тварин піддослідних груп відносно контролю та попереднього дослідження не відбулося. У порівнянні з початковими показниками кількість еритроцитів достовірно збільшилася тільки у тва- рин $\mathrm{CH}$ і С типів ВНД, хоча їх параметри суттєво не відрізнялися від показника груп СВР та СBI типів на 20-у добу експерименту.

Подальше задавання препарату сприяло активізації процесів гемопоезу в організмі свиней.

Так, установлено достовірне підвищення кількості еритроцитів у крові тварин СВР типу на 30-у і 40-у добу досліду відносно початку експерименту на $8,78(\mathrm{p} \leq 0,05)$ та $20,00 \%(\mathrm{p} \leq 0,01)$ та на 40-у добу порівняно з тваринами контрольної групи (на 17,93 \% при $\mathrm{p} \leq 0,01$ ).

Свині СВІ типу ВНД на 30-у добу зміною кількості еритроцитів у крові не відреагували як відносно інтактного стану, так і по відношенню до контрольних тварин, а на 40-у добу показали тенденцію до перевищення контрольних тварин на $13,97 \%$.

У крові свиней СН типу ВНД на 30-у та $40-\mathrm{y}$ добу досліду відносно початкового стану кількість еритроцитів збільшилася, відповідно, на 20,78 та $31,26 \%(p \leq 0,001)$, а порівняно 3 тваринами контрольної групи - на $6,12 \%$ (не достовірно) та $16,55 \%(\mathrm{p} \leq 0,01)$. Від тварин інших типологічних груп свині СН типу ВНД суттєво не відрізнялися.

У свиней С типу на 30-у та 40-у добу досліджуваний показник достовірно збільшився на відповідно 20,30 \% та 32,43 \% відносно початку досліду, а на час закінчення експерименту (40-а доба) був на $15,82 \%$ вищим $(\mathrm{p} \leq 0,05)$, аніж у контрольних тварин. Зазначимо, що тварини слабкого типу ВНД наприкінці дослідження мали найнижчу кількість еритроцитів крові 3поміж представників інших типологічних груп, що було достовірним у порівнянні зі свинями CBP типу (на 7,38 \% за $\mathrm{p} \leq 0,05$ ). 


\section{ВЕТЕРИНАРНА МЕДИЦИНА}

Аналізуючи динаміку кількості еритроцитів у крові тварин із різними характеристиками процесів збудження та гальмування у корі півкуль великого мозку можна припустити, що переважний вплив на даний показник має сила нервових процесів.

\section{БІБЛІОГРАФІЯ}

1. Зориков А. Ю. Влияние биологически активного йода на воспроизводительные, продуктивные и мясные качества свиней / А. Ю. Зориков. - Автореф. дисс. ... канд.. с.-х. наук: 06.02.08. - Курск: ФГБОУ ВПО «Курская государственная СХА им. проф. И. И. Иванова», 2012. - $18 \mathrm{c}$.

2. Карповський В. I. Типи вищої нервової діяльності великої рогатої худоби та характер адаптаційних реакцій на дію зовнішніх подразників / В. І. Карповський. - Автореф. дис. ... д-ра. вет. наук: 03.00.13, 16.00.02. - НУБіП України. - К.,
Висновок. Застосування свиням препарату «Йодіс-концентрат» у дозі 0,12 мг на 1 кг маси тіла двічі на добу впродовж 40 діб сприяє збільшенню кількості еритроцитів крові, передусім у тварин сильних типів вищої нервової діяльності, що підвищує резистентність їх організму.

2011. $-42 \mathrm{c}$.

3. Монцевичюте-Эрингене Э. В. Упрощенные математико-статистические методы в медицинской исследовательской работе / Э. В. Монцевичюте-Эрингене // Патол. физиол. и экспер. терапия. - 1964. - Т. 8, № 4. - С. 71-78.

4. Решение проблемы йододефицита: «Йодисконцентрат». - Електронный ресурс. - Режим доступа: http://www.jodis-k.com/index.php?option=com_content\& view $=$ article\&id=8\&Itemid=31\&lang-ru. -11.05 .2012 .

5. ТУ У 14326060.003-98. Сировина для виробництва йодованих продуктів «Йодіс-концентрат» 